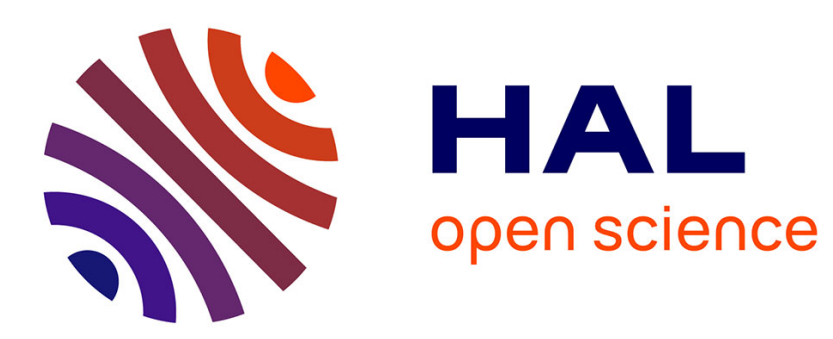

\title{
Müste'min Dealing with the Ottoman Justice: Role and Strategy of the Ambassador
}

Juliette Dumas

\section{To cite this version:}

Juliette Dumas. Müste'min Dealing with the Ottoman Justice: Role and Strategy of the Ambassador. Oriente Moderno, 2013, 93 (2), pp.477-494. 10.1163/22138617-12340028 . hal-02116406

\section{HAL Id: hal-02116406 \\ https://hal.science/hal-02116406}

Submitted on 30 Apr 2019

HAL is a multi-disciplinary open access archive for the deposit and dissemination of scientific research documents, whether they are published or not. The documents may come from teaching and research institutions in France or abroad, or from public or private research centers.
L'archive ouverte pluridisciplinaire HAL, est destinée au dépôt et à la diffusion de documents scientifiques de niveau recherche, publiés ou non, émanant des établissements d'enseignement et de recherche français ou étrangers, des laboratoires publics ou privés. 


\title{
Müste'min Dealing with the Ottoman Justice: Role and Strategy of the Ambassador
}

\author{
Juliette Dumas \\ Collège de France, Institut des études turques, arabes et islamiques - Paris
}

\begin{abstract}
Because of their status as foreigners, non-subject of the Empire, müste'min are subject to a system of laws different from the other subjects of the Empire. They also benefit from advantages secured by the granting of imperial orders: the 'ahidnâme also known as the capitulations: these are prescriptions issued by the sultan, directly influenced by political and economic aspects and which may vary from one nation to another. However, it is not a code of law different from others in force in the Empire: except in specific cases prescribed by the capitulations, the müste'min are submitted as other Ottoman subjects to the Ottoman legal system.

Nevertheless, the Ottoman legal system is complex: the actors and the practices vary and depend on the individuals involved and cases. Therefore, the question is who are the interlocutors of the müste'min? The documents examined here show that the type of conflicts impacted on the interlocutors that were involved. Each time the case involves, in one way or another, the privileges of the müste'min from a given nation, the imperial divan had to solve the case- then, it usually refers to the local court. But if private, the case was directly submitted to the kadı. The call for submission of cases to the Imperial divan is interesting because it shows that confidence is put in the Imperial divan rather than in the kadı. Perhaps, it also reveals the limits of the legal knowledge of the privileges and the special rights granted to müste'min. In fact, the population concerned by the Capitulations was minor and the affairs affecting them probably rare, as a result, one should not be surprised by the lack of knowledge of the local actors, of their privileges.

The role of the embassy and of the ambassador must also be emphasized here. In our documents, it appears that the embassy as a whole played a significant role in supporting its citizens through legal advice, assistance and support. The French embassy even seems to have distinguished itself on this item since the legal support offered was presented by the ambassador.
\end{abstract}

\section{Keywords}

Müste'min; Zimmi; Trans-Imperial Subjects; Galata; Kadıs Court 
The Ottoman Empire was, from its origins, multi-cultural and multireligious and this is probably one of the most exciting aspects which had surely surprised the observers of the Empire (especially according to the respective situations of the Western countries). Some non-Muslim populations were tolerated and even protected within the Empire because it was established by the Islamic religion: for the "People of the Book", including the Christians and the Jews, the right to exist was recognized (the rights to practice their religion, to preserve their religious rites, to live according to their mores and customs). These populations whose rights are guaranteed by Islamic precepts, are called zimmi (Arabic, $\underline{\operatorname{dimm}} \bar{\imath}$ ). The Zimmis were certainly not equal to Muslims: although they were allowed to live according to their beliefs and customs, they were also subjected to additional taxes (including the harac; Arabic, harāăg) and suffered from regular abuses or deprivations, from individuals as well as from the state.

Zimmis were inhabitants of the Empire. These minorities are inherent to the Empire and even though they benefit from specific rights, they are included in the Islamic legal system. The situation is quite different for temporary residents who obey to another legal status, known under the name müste'min, "foreigners". These individuals may inhabit for a more or less long term in Ottoman territories, but they are never considered as subjects. This difference in status justifies and requires a difference of rights. As nonsubjects of the Empire, they are not tied by the rules in force. Nevertheless, there was a need to lay down rules for them, in order to define their rights and determine on which basis they could be judged.

It is interesting to observe that the Ottoman legislation dealing with those individuals is linked to both diplomatic and commercial aspects. Indeed, the basis of the regulation regarding these individuals and their rights cannot be found in the šar'́ah or in the kanunnâme, but in the 'ahdnâme ('ahıdnâme), known in the West as Capitulations. ${ }^{1}$ However, these capitu-

1 On the ambivalence of this specific status, see Veinstein, Gilles. "The status of musta'min between Law and Politics". In: The Ottoman Empire. Myths, Realities and 'Black Holes'. Contributions in Honour of Colin Imber. Evgenia Kermeli and Oktay Özel (eds). Istanbul, Isis, p. 189-201. There is also a significant literature on trade and diplomatic relations between the Ottoman Empire and its neighbours (particularly Western). See, for example Masson, Paul. Histoire du commerce français dans le Levant au XVII siècle. Paris, Hachette, 1896; Id. Histoire du commerce français dans le Levant au XVIII ${ }^{e}$ siècle. Daniel Panzac (ed.). Paris, Hachette, 1911; Les Ottomans en Méditerranée: navigation, diplomatie, commerce. ROMM, 39, 1 (1985), p. 1-244; Veinstein, Gilles. "L'Europe et le Grand Turc". In: L'Europe et l'Islam:quinze 
lations are based on diplomatic relations established between the Ottoman State and the neighbouring powers (including the West) and whose stakes were the establishment of economic exchanges as well as the protection of subjects of these respective states. ${ }^{2}$ Two among the several characteristics of the capitulations are worth recalling here. First, its temporary nature has to be emphasized: according to the Ottoman definition, a 'ahdnâme is an order issued by a Sultan, and, as any other edict issued by a Sultan, its validity is only guaranteed by his authority. If the Sultan happens to die, all the measures become obsolete- until his successor decides to renew it. ${ }^{3}$ Because of this situation, at a beginning of a new reign, the diplomats could renegotiate all the measures decided by the previous sovereign - this situation not only presented disadvantages, since it was also the opportunity to negotiate new favours. The second specificity of these capitulations consists precisely in its diversity: the capitulations established for a country were only valid for it. Thus, the neighbouring countries of the Ottoman Empire did not always benefit from diplomatic and commercial agreements, and those who did, were not necessarily equally treated with each other. ${ }^{4}$

siècles d'histoire. Gilles Veinstein, et al. (eds). Paris, Odile Jacob, 20og; Çiçekoğlu, Feride; Edhem, Eldem. La Méditerranée turque. Paris, Maisonneuve et Larose, 2000; Eldem, Edhem. French Trade in Istanbul in the Eighteenth Century. Leiden, Brill, 1999; Poumarède, Géraud. Pour en finir avec la Croisade: mythes et réalités de la lutte contre les Turcs aux XVIe et XVII ${ }^{e}$ siècles. Paris, PUF, 2004.

2 Edhem, Eldem. "Capitulations and Western Trade". In: The Cambridge History of Turkey. Vol. 3: The Later Ottoman Empire, 1603-1839. Suraiya Faroqhi (ed.). Cambridge, Cambridge University Press, 2006, p. 283-335; Poumarède, Géraud. "Négocier près la Sublime Porte: jalons pour une nouvelle histoire des capitulations franco-ottomanes". In: L'invention de la diplomatie. Lucien Bély (ed.). Paris, PUF, 1998, p. 71-85; Veinstein, Gilles. "Les préparatif de la campagne navale francoturque de $155^{2}$ à travers les ordres du divan ottoman". Revue de l'Occident musulman et de la Méditerranée, 39, 1 (1985), p. 35-67; Charrière, Ernest. Négociations de la France dans le Levant. 4 voll., Paris, Imprimerie nationale, 1840-60.

3 Veinstein, Gilles. "L'empire dans sa grandeur (XVI e siècle)". In: Histoire de l'Empire ottoman. Robert Mantran (ed.). Paris, Fayard, 1989, p. 167-169; Vatin, Nicolas; Veinstein, Gilles. Le Sérail ébranlé. Essai sur les morts, dépositions et avènements des sultans ottomans, XIV -XIX ${ }^{e}$ siècle. Paris, Fayard, 2003, p. 82-86.

4 In the XVIth century, the main foreign merchants were Venetians, Genoese, Ragusans, Moldavians, Wallachians, Poles or Russians, because of relationships and agreements more or less old. It was not until 1569 (although a first agreement, obviously not ratified, was negotiated in 1536) that the French benefited from a 'ahidnâme. This example was soon followed by the British and the Dutch who, after 
Thus, Capitulations were imperial orders which granted specific privileges to specific groups of foreigners whose right is to be named müste'min. A müste'min is not a foreigner like others: he is recognized as a foreigner with several rights but he has also numerous duties. And these rights and duties were evolving according to the periods and the nationalities. Within the framework of this paper, we will focus on foreigners' legal status while trying to understand how "foreigners" were settling legal issues.

To do so, retrieving the sicill of kadı (Arabic: $q \bar{a} d \bar{l}$ ) turned out to be interesting. Sicill are records prepared by the staff of the court of the kadı (i.e. local "judge") that keeps track of cases that were submitted to him. ${ }^{5}$ Its formulation is elaborated to meet the legal codification in force: which means it is not possible to get the exact transcript of words and events that occurs. The sicill we chose to study are the ones from the kadis court of Galata from the XVIIth century, recently published by Timur Kuran in the first volume of Social and Economic Life in Seventeenth-Century Istanbul. ${ }^{6}$ In this volume, several cases refer to various people working for embassies, including the ambassador and his dragoman, ${ }^{7}$ as well as a significant number of traders - all foreign. Through the study of müste'min, it is the embassies' daily legal activities that received more of our attention. This item is relevant since one of the ambassadors' roles was to make sure the rights of their compatriots were respected. We will be focusing on the case of three Western States' embassies: France, Britain and the Republic of Venice. ${ }^{8}$

having traded under the French flag, eventually acquire their own capitulations in 1580 and 1583 for the first, 1612 for the latter.

5 S.v. «Sicill» (Virginia Vacca), İslâm Ansiklopedisi; s.v., «Sidjill» (Faroqhi Suraiya), $E I^{2}$; Jennings, Ronald C. "Kadi, Court and Legal Procedure in 17 th Century Ottoman Kayseri”. SI, 48 (1978), p. 133-172.

6 Kuran, Timur. Mahkeme Kayıtları Işığında Sosyo-Ekonomik Yaşam/Social and Economic Life in Seventeenth-Century Istanbul. Glimpses from Court Records. Istanbul, Türkiye İş Bankası Kültür Yayınları, 2010 (vol. 1: Esnaf ve Loncar; Hıristiyan ve Yahudi; Cemaat İşleri; Yabancılar / Guilds and Guildsmen; Communal Affaires o Christians and Jews; Foreigner).

7 The term "dragoman" refers to the individuals responsible for all translation activities for the consulates and embassies in the Empire. See, for example Testa, Marie de; Gautier, Antoine. Drogmans et diplomates européens auprès de la Porte ottoman. Istanbul, Isis, 2003; Hitzel, Frédéric. Enfants de langue et drogmans / Dil oğlanlarıve tercümanlar. Istanbul, Yapı Kredi Yayınlar, 2005.

8 The presence of these three embassies is not surprising at the time. Venice was a major trading partner of the Empire in the XVIth century (although the competition was tough, especially with other Italian cities), and France succeeded in 


\section{Knowing the System ... and Benefeting from it}

Were müste'min aware of the Ottoman legal system? Many studies dealing with zimmi have shown that they were fully informed about the Ottoman judicial system and about the benefits that could be provided and they did not hesitate to resort to it - even though their legal status offered them the ability to follow the rules of their communities. Thus, it is not uncommon to see zimmi women preferring Islamic justice to theirs, especially regarding matrimonial cases as the Islamic right were often more favourable to them. ${ }^{9}$ It is not uncommon to see cases of litigation in which both parties are zimmi sharing the same religious confession and who chose the intervention of the kadı rather than their own courts..$^{10}$ As they are subjects of the Empire, it is not surprising that they are well informed of the dominant judicial system. This is less obvious in the case of müste'min: as subjects of another State, nothing could predict they could have been aware of judicial practices in force in the Ottoman Empire in which they were only passing

establishing itself both as a political and commercial partner of the Empire in the second half of the XVIth century, and was quickly followed by Britain at the turn of the XVIIth century. Therefore, these three States were best located in the capital and in the Empire in the XVIIth century. Only the lack of Holland, who joined this little group in 1612, is surprising; however, the record does not count any order relating to its citizens. As for states that were not benefiting from agreements, it is not surprising to not find cases regarding them.

9 Salakides, Georgios. "Women in the Kadı Sicilleri of Yenişehir (Larissa) in the Middle of the Seventeenth Century". In: Festschrift Hans Georg Majer. Arts, Women and Scholars. Sabine Prätor; Christoph K. Neumann (eds). 2 vols., Istanbul, Simurg, 2002, p. 209-228; Jennings, Ronald C. "Women in Early 17th Century Ottoman Judicial Records - the Sharia Court of Anatolian Kayseri”. JESHO, 18 (1975), p. 53-113; Id. "The Legal Position of Women in Kayseri, a Large Ottoman City, 1590-1630". International Journal of Women's Studies, 3 (1980), p. 559-582; Id. "Divorce in the Ottoman Sharia Court of Cyprus, 1580-1640". SI, 78 (1993), p. 155-167; Veinstein, Gilles. "Femmes d'Avlonya (Vlöre) vers le milieu du XVIe siècle d'après les actes des qadis)". In: Festschrift Hans Georg Maje. 195-208; Zarinebaf-Shahr, Fariba. "Ottoman Women and the Tradition of Seeking Justice in the Eighteenth Century". In: Women in the Ottoman Empire. Middle Eastern Women in the Early Modern Era. Madeline C. Zilfi (ed.). Leiden-New York-Köln, Brill, 1997, p. 253-263.

10 Jennings, Ronald C. "Studies on Ottoman Social History in the Sixteenth and Seventeenth Centuries. Women, Zimmis and Sharia Courts in Kayseri, Cyprus and Trabzon". Analecta Isisiana, 39, Isis, Istanbul, 1999; Gerber, Haim. Islamic law and culture, 160o-1840. Leiden, Brill, 1999. 
through. Thus, it seems useful to start by questioning the degree of knowledge that these individuals had of the Ottoman legal system.

The first litigation, brought to the kadı of Galata in 1683, gives some clues about the topic. A man named Dimitri, an inhabitant of the Morea and guest in Galata, presses charges against the ambassador of France "Kelaraga", i.e. the Count of Guilleragues, Lavergne ${ }^{11}$ who is represented by the Captain "Badiye". Dimitri complained of not receiving full payment for a work done for the Count of Guilleragues. When consulted, the ambassador's party refutes the charge: the full payment has been made and recognized by the court. There are witnesses to attest it, if necessary. As Dimitri keeps refusing to recognize the facts, the judge summoned the witnesses, which led to the exoneration of the French ambassador. ${ }^{12}$

This document reveals a thorough understanding of the Ottoman legal system. Before the litigation, the French Ambassador took the precaution to go (or more likely to send a representative) to court with the sole purpose to make officially be recognized and unassailable the full payment of the amount he owed to Dimitri. It seems likely that he has received a written document attesting this fact, although we found no mention of it: the assertion of his witnesses was sufficient, or preferable. According to this document, there was a thorough knowledge of the judicial system but this phenomenon could be explained by the way the sicill were recorded. Only the information deemed useful was formatted in a purely judicial language. It is also possible that the representative of the Ambassador has provided documents or witnesses that were not required by the Ottoman procedures, which are not even mentioned in the report, because they were not valid from the Islamic legal point of view. However, the fact that the ambassador took the precaution to go to court in order to certify he paid his due to Dimitri shows a precise knowledge of the judicial system - such as an obvious lack of confidence in his employee. This practice was very common in the Empire and is not only the fact of "foreigners" or zimmi. ${ }^{13}$

11 Like many of his colleagues, this ambassador maintained an extensive correspondence, which was published by Frederick Deloffre and Rougeot Jacques: Guilleragues, Earl Gabriel Joseph de Lavergne. Geneva, Droz and Paris, Champion, 1976. He is also the author of letters attributed for a long time to Mariana Alcoforado. These were also published in several languages (including French and Turkish).

12 Kuran. Mahkeme Kayıtları. N ${ }^{\circ}$ 442, p. 843-845 (Galata 130: 17b/1-1683).

13 The sicill we consulted shows it and many of the acts therein correspond to acknowledgment of debt, statements of payment for service rendered or 
Other cases exemplify the fact that müste'min (at least people working for embassies) were fully informed of their rights to the point that they benefited from them! The following case gives an idea about it: in 1661, Mustafa, a bölükbaşı from Algiers, presses charges against the Ambassador of the United Kingdom, named "Vazcelis", ${ }^{14}$ represented by the interpreter of the Embassy (named Likaro). He asserts that, in Algiers, after having announced that he was going to sail to Istanbul, the ambassador invited him to embark with him, giving him assurance for financial compensation if any losses would occur during the journey. Unfortunately, they were forced to halt at Syria and suffered from damages resulting of revolts that were occurring in the country at that time. However, when Mustafa asked for compensation because of the loss of his business, the ambassador who committed himself rejected him. Mustafa went to court and the ambassador, via his interpreter, used his privileges based on the 'ahdnâme established between his country and the Empire, which states that English müste'min cannot be prosecuted in court without a hüccet. Besides, it is not permitted to use against them the statements of potential witnesses. ${ }^{15}$ Presented to the judge and added to the file, ${ }^{16}$ these privileges eventually resulted in the rehabilitation of the ambassador.

The flatness of this document does not provide any particular comments. Nevertheless, if we read between the lines, we can find in fact a good example of fraud. Indeed, we are dealing here with a common case of maritime caravan: an individual asks for boarding, with his goods, probably against some payment. However, Mustafa was wrong in failing to establish a contract with the ambassador. This type of contract is easily found for

reimbursement of a debt. See, for instance, the sicill in Üsküdar is published by the ISAM under the title İstanbul Kadı Sicilleri Üsküdar Mahkemesi, ISAM Yayınları (several volumes and dates).

14 It seems that it is a reference to the Earl of Winchelsea, Sir Heneage Finch, ambassador between the years 1660 and 1669 . His predecessor, Sir Thomas Bendish, seems to have remained in office until his arrival. Therefore, we can date back the travel of the count somewhere between late 1660 and early 1661 the year-which would be consistent with the nature of the complaint against him in 1661.

${ }_{15}$ Kuran. Mahkeme Kayıtları. 우 436, p. 830-832 (Istanbul 9: 19a/1-1661).

16 The documents given by the party of the ambassador are capitulations as well as fetva issued by the şeyhülislam ("tuğrâ-yı garrâ-yı Sultânî ile mahallî ahidnâmeleri ve şeyhülislâm hazretlerinden fetvâyı". Kuran. Mahkeme Kayıtları. No. 436 , p. $830-832$. 
the following century, as Daniel Panzac ${ }^{17}$ showed—and no doubt existed in the late XVIIth century. Did Mustafa think that a verbal agreement was sufficient? It seems also possible that for several reasons this arrangement was unofficial. Nevertheless, his words might have been sufficient in court, if there were no ambassadorial privileges. Contrary to the ambassador, it is possible that Mustafa had no clue about such privileges: it is much less unlikely that he was not aware of his rights. It is hard to believe that an ambassador could face the unknown without taking time to be informed about his situation and privileges ... In Algiers, the ambassador would have made the bet that he was going to win in any case: he was most probably paid for the trip and pledged his word on a point of law he could not be required to comply.

We further strengthened our idea that we have here a case of fraud because this complaint is far from being one of a kind. In fact, most of the complaints against an ambassador or a member of an embassy (often the interpreter) is similar to our case: an individual complains that while he received guarantees for the transport of its goods on the boat of an embassy (the British Embassy is not the only one involved in this kind of cases), the reimbursement for damages - while he received a verbal agreement - is denied. ${ }^{18}$ If this case was unique, it could give us a doubt, but its repetition suggests that, for embassies, this was a common practice, based on illicit agreements, as their perpetrators were protected by their privileges granted by the Capitulations. Nonetheless, this is only possible if we agree with the fact that the ambassadors and their staff (especially the interpreters) were fully informed about their rights and privileges — and that they knew how to take advantage of these while sometimes bordering with illegality.

17 Panzac, Daniel. "Affréteurs ottomans et capitaines français à Alexandrie". ROMM, 34 (1982), p. 23-38; Id. "Les échanges maritimes dans l'Empire ottoman au XVIIIe siècle”. ROMM, 39 (1985), p. 177-188 and above all, Id. La caravane maritime. Marins européens et marchands ottomans en Méditerranée (1680-1830). Paris, CNRS Editions, 2004.

18 Kuran. Mahkeme Kayıtları. $\mathrm{N}^{\circ}$ 420, p. 806-810 (Galata 27: 83a/1-1605); n ${ }^{\circ} 436$, p. $830-832$ (İstanbul 9: 19a/1-661); $\mathrm{n}^{\circ}$ 440, p. 838-842 (İstanbul 9: 222b/1: 1662); $\mathrm{n}^{\circ} 453$, p. 861-863 (Galata 145: 48a/1-1689). 


\section{A müste'min Responsible for the Others: The Ambassador}

After seeing that müste'min working for Western embassies were fully informed of the Ottoman legal system, let us examine how it was used. To do so, a distinction has to be made according to situations. From our sources, diverse scenarios emerges which will be the subject of a further investigation within this paper. First of all, we will focus on the case of judicial interventions within the areas of responsibility of ambassadors. In other words, they are not solicited for private reasons, but within the framework of their role as protector of their community. Three examples have been selected in which the case led to the involvement of three different ambassadors: that of France, the lease of Venice and a representative of Great Britain.

Let us highlight the common feature of all these cases: the bias of the Imperial Council, the Divan. Whenever the interests of müste'min from a community (France, Venice or England) are threatened and that the Embassy is required (in one way or another), the conflict is always brought to the imperial justice and not to the court of the kadı. We will examine the reasons of this phenomenon in the light of selected examples.

In 1604, the Ambassador of France petitioned the Palace: the consul of France supported by another müste'min named Bernardo are complaining of an attack launched against them in Bandirma. The attackers entered Bernardo's house and took his belongings, including two cariye (Arabic, ğa ariyah). After he has been warned, the ambassador of France asked for justice at the imperial divan, demanding the restitution of the aforesaid. He provided for this purpose the document of the French capitulations. It stated that no one can interfere with French subjects, members of the embassy or consulates, living in the commercial cities of the Empire. ${ }^{19}$ Given this case, the Imperial Council issued an order to the judge of Galata, commanding him to seize and to condemn the criminals involved, if they belong to his jurisdiction. In case of resistance, the kadı will have to send them to the Palace for their trial. ${ }^{20}$

19 "France ilçisi dergâh-ı mu'allâma arzıhâl gönderüp ellerinde ahidnâme-i hümâyunda benderlerde olan konsoloslara ve sâyir Francelülere bir vechile dahl olunmaya deyü mestûr olup"; Kuran. Mahkeme Kayıtları. 792.

20 Kuran. Mahkeme Kayıtları. $\mathrm{N}^{\circ}$ 410, p. 791-793 (Galata 25: 83b/1-1604). 
The same year, the Imperial Council is again solicited, this time, by a Venetian, a merchant named Pablos, who sent to this effect a representative (perhaps a member of the embassy?). ${ }^{21}$ This correspondent recalled that according to the privileges granted by an imperial order, ${ }^{22}$ the Venetians can import, each year, an amount of alcohol of 10 ooo mühde free of charge. However, the customs officers clearly intended to charge Pablos. The merchant's correspondent provided to the Divan an imperial order, which referred to the last Capitulations granted to the subjects of the Venetian Republic. The Imperial Council transferred the case to the judge of Galata - that has to give justice while taking into account the privileges of the Capitulations.

Eventually, the following year, the British Embassy solicited the Divan: the custom was that the dragomans of the embassy were free from all tribute and taxes. ${ }^{23} \mathrm{~A}$ decree was even issued about it. That year, the embassy happened to change the translator: therefore, the Ambassador asked for the renewal of the decree in favour of his new interpreter, which eventually was done. ${ }^{24}$

In view of these three examples, it appears that the embassies were using different strategies. Obviously, when the interests of their subjects were threatened, the three embassies were establishing contact with the Imperial Court. Nevertheless, it seems surprising that the complainants were holding imperial documents referring to their rights and privileges. In that case, we may wonder why they need to refer to the Imperial court since, with such documents, they could simply go to the judge: their complaints would have been taken into account in the same way and the outcome would have been similar-or can be imagined from a legal point of view. ${ }^{25}$ Moreover, we can note that the Imperial Council always transfers the case to local kadı (here the one of Galata). The fact that they feel the need to refer to the imperial court is as surprising as interesting, especially

21 Kuran. Mahkeme Kayıtları. $\mathrm{N}^{\circ}$ 411, p. 793-794 (Galata 25: 91a/3-1604).

22 The document do not refer to a 'ahdnâme but a emr-i şerîf. Kuran. Mahkeme Kayıtları. 794 .

23 The dragomans of the English embassy were not the only ones to benefit from advantages because of their position. See Veinstein, Gilles. "Les privilèges du drogman de Venise à Alep au début du XVII ${ }^{\mathrm{e}}$ siècle”. In: Méditerranée, MoyenOrient: deux siècles de relations internationales. 25-41.

${ }^{24}$ Kuran. Mahkeme Kayıtları. $\mathrm{N}^{\circ}$ 422, p. 812-813 (Galata 27: 88a/1-1605).

25 The English case is to be set apart because it aims to communicate a change of staff. As a result, the imperial administration has to be informed first. 
because this is a general rule, found to be identical in all consulted cases. Our hypothesis is that the müste'min working in embassies put more confidence in the imperial court than in local courts.

The similarity between these three embassies only lies in this item because significant differences can also be highlighted from these examples. Thus, the French Embassy seemed to follow a strategy of centralization of cases: the ambassador submits all cases and complaints to the Palace.

However, this centralizing strategy is only attested in cases involving French subjects. The Venetians and the English had a different method: the complaints are submitted directly and nominally by the complainant to the Divan. Their ambassadors may not be involved as representatives but this does not imply that they do not follow the litigation. Let us review more accurately the Venetian case. If Pablos holds a copy of the imperial decree, we can assume that it was given to him from his ambassador. It is doubtful that each of the Venetian subjects holds a copy of the decrees on their rights and privileges! Thus, the Venetian and British embassies were giving their compatriots legal support and advice without being officially involved.

Now, let us come back to the item of the preferential use of imperial justice which may be surprising in such cases of little importance. It was common for the ambassadors and their staff to contact, and sometimes to go personally, to kadıs. Here, we can see that there is a relationship between the subjects involved in the case that always affects the rights and privileges granted to müste'min via the Capitulations-and the role of ambassadors as representatives of the interests of their compatriots.

The following example is offering a more accurate idea about it. In 1696, an English trader named Corco (?) was sued by Manol, Yani's son and heir, and Dimitri, because of a business issue. ${ }^{26}$ Both plaintiffs ask for financial compensation from Corco who refused to comply with their demand. As a defense, he claims to hold a document that he received from Yani (we understand that meanwhile he died) who freed him from all responsibility and financial burden. The document provided by the English merchant is red in the presence of the judge, and translated by Antonali, the chief dragoman of the British Embassy, and Iskarlet, an Imperial dragoman.

In the present situation, the case was not brought to imperial court, however, the British ambassador sent the chief translator (supervised by an imperial dragoman). The case reached a high level and is as a result,

26 Kuran. Mahkeme Kayıtları. № 468, p. 891-894 (Istanbul 22: 36a/2-1696). 
fully considered. Nonetheless, the ambassador was absent and his strategy appears to give coherence to what is said above: he provided his support to his compatriot by delegating his power to his dragoman while refusing to get personally involved. ${ }^{27}$

The principal difference between this case and the previous ones lies on the fact that the müste'min got personally involved in a commercial matter that does not affect the rights and privileges guaranteed by the capitulations - this phenomenon is illustrated by the fact that here, the müste'min is not the plaintiff but the defender. This situation permits support from the embassy but does not require a direct official intervention. This is even more obvious in many similar cases involving French subjects who are brought to the kadi's court without any interference from the ambassador, unlike the strategy of centralization followed by the embassy.

Western ambassadors obviously appear to refer (directly or indirectly) to imperial justice when national privileges are threatened and this is part of their role as protectors of their compatriots. Though, in other cases, they relegated their support to their subordinates, thus, the area of action was not the Imperial Divan anymore but the local court.

\section{A müste'min Like Others: The Ambassador vs. the Kadı}

Certainly, the ambassador was the representative of his king's subjects to the Ottoman authorities but as soon as he was leaving his office, he was becoming a müste'min like any other, who could potentially be summoned to the Ottoman court. Therefore, his interlocutor was not the Imperial Divan but the local $k a d$, the one of Galata. ${ }^{28}$ Thus, for his notarial affairs, he can refer to the kadı as everyone does, whether Muslim, zimmi or müste'min. $\mathrm{He}$ is also summoned to the judge to deal with the charges against him.

27 On this topic, see Margherith, M.C. Etude sur les fonctions des drogmans des missions diplomatiques ou consulaires en Turquie. Constantinople, 1898; Testa Marie de, Gautier Antoine. op. cit.

28 Western ambassadors' residences were all located in the area of Pera, in the Galata neighborhood; thus, under the jurisdiction of the judge of Galata district. Casa, Jean-Michel. Le Palais de France à Istanbul:un demi-millénaire d'alliance entre la Turquie et la France / Istanbul'da bir Fransız Sarayı: Fransa ile Türkiye arasında 500 yıllı ittifak. Istanbul, Yapı Kredi, 1995; Hoenkamp-Mazgon, Marlies. Palais de Hollande in Istanbul. The embassy and envoys of the Netherlands since 1612. Amsterdam, Boom, 2002. 
During the XVIIth century, the French Embassy experienced, several times, disagreements with the double-hatted kadı who was both a notary and a judge, as the two following examples attests.

In the early XVIIth century, two ambassadors of France refer to the kadı of Galata: Francesko Beyzade (i.e. François Savary de Brèves, Ambassador of France to the Porte from 1589 to 1607) and Covan veled-i Baronbar (i.e. Jean-François de Gontaut-Biron, baron Salignac, his successor from 1607 to 1611$).{ }^{29}$ Both are introduced by their translators, Domoniko and Ligor, acting on their behalf. The case is simple: François announces the sale of his house in Galata to Jean-François, for 600.000 akçes. The kadı was asked to confirm the sale and to provide a guarantee of validity, so that no problem could arise over the legal possession of the property by JeanFrançois. It seems obvious that the two ambassadors, probably at François Savary's instigation, who appears to be well informed of legal and notarial practices in force in the Empire, intended to protect himself from a potential risk of seizure of his property.

This case highlights several practical aspects of the work of ambassadors. While he was in office, François Savary acquired a house worthy of his rank. ${ }^{30}$ Recalled to France, this residence became useless for him, while his successor, Baron de Salignac, found an immediate use of it. The handover of powers between the two ambassadors required a real estate transaction as well, following the Ottoman customs in force and certified by the kadı. Although the case involves the two ambassadors, their solicitation by the Ottoman justice is not official but private: they are two müste'min, among others, that goes to the kadı. Nothing, except the mention of their names, titles and the presence of their dragoman makes the distinction between them and the others in the exercise of justice.

29 Kuran. Mahkeme Kayıtları. No 416, p. 801-802 (Galata 27: 23b/4-1604). On French ambassadors in the Ottoman empire, see Représentants permanents de la France en Turquie (1536-1991) et de la Turquie en France (1797-1991). Bacqué-Grammont et al. (eds). Varia Turcica, 22, 1, Istanbul, Isis, 1991; Gontaut-Biron, Jean de. Ambassade en Turquie de Jean de Gontaut-Biron, baron de Salignac, 1605 à 1610 . Paris, Champion et Picard, 1889; Biran, Elie de. Une ambassade de France en Turquie sous Henri IV: Jean de Gontaut-Biron, baron de Salignac (1605-1610). Meulan, [s.n.], 1881; Tongas, Gérard. Les relations de la France avec l'Empire ottoman durant la première moitié du XVII e siècle et l'ambassade à Constantinople de Philippe de Harlay, comte de Césy (1619-165o). Toulouse, Boisseau, 1942.

30 According to the price of the sale (600 ooo aspres), it is an important residence. 
However, the ambassador of France can also be summoned to court to deal with charges against him. That is precisely what happened to François Savary, who obviously had a sustained legal activity during the eight years of his term. The charges were laid in 1604 by Ismihan, the widow of a man named Debane, who seems to have been a member of the staff of the French Embassy, and the legal guardian of their son, Muștafà. She was represented by a significant character: a man named Mehmed Bey. At Deban's death, the embassy confiscates and seizes his property as well as all his belongings. The widow encountered difficulties in recovering her son's heritage and presses charge against the ambassador. Eventually, this case required several interventions from the judge and thus, is registered on three sicill. ${ }^{31}$

Admittedly, some parts of this file remain obscure. The legal status of the widow is not clear: non-Muslim originally, she converted after her husband's death, presumably to strengthen the case. ${ }^{32}$ Indeed, her conversion is a common practice for zimmi women encountering marital difficulties. ${ }^{33}$ Some of them converts in order to ask for a divorce, which is forbidden by the Jewish or Christian Orthodox religions, or at her husband's death, to ensure the payment of their rights, that is to say, the dower (mehr), her inheritance and eventually her children's inheritance. In the absence of results of the first two attempts to go to court, she might have chosen to convert. While becoming a Muslim, she enters the part of the society that the judge must, above all, protect and defend the rights, as women, children and orphans.

Was François Savary heartless and trying to steal the poor woman and her son's inheritance? The legal strategies developed by Ismihan should not mislead us. According to the privileges guaranteed by the capitulations, the property of a French person without heir and who died within the Empire belongs by right to the embassy. ${ }^{34}$ Since Ismihan's status was not clear, the Embassy could seize Debane's property. Obviously, François Savary was not willing to make way for the widow and his son, nonetheless, he was acting according to the law of the müste'min under his authority. Ismihan found herself facing a legal loophole against which the only remaining strategy was to convert. In this way, as a Muslim, her rights come within the Islamic

31 Kuran. Mahkeme Kayıtları. $\mathrm{N}^{\circ}$ 413, p. 795-797 (Galata 27: 21b/2-1604); $\mathrm{n}^{\circ}$ 414, p. 797-798 (Galata 27: 21b/3-1604); ${ }^{\circ} 415$, p. 798-801 (Galata 27: 22b/2-1604).

32 Kuran. Mahkeme Kayıtları. $\mathrm{N}^{\circ}$ 415, p. 798-801 (Galata 27: 22b/2-1604).

33 See note number 9 .

34 Kuran. Mahkeme Kayıtları. $\mathrm{N}^{\circ}$ 415, p. 798-801 (Galata 27: 22b/2-1604). 
right. This strategy turned out to be successful: the court's determination was the recognition of the rights of the widow and her son. As a result, the French ambassador had to pay Ismihan the amount of her mehr and her inheritance as well as the inheritance that was due to her son, and which as a legal guardian, she is responsible for until her child's majority. ${ }^{35}$

What makes also this case special is the fact that when François Savary seizes Debane's belongings, he acts according to the privileges of the Ambassador of France. In other words, this is as part of his duties. And yet, it is not the ambassador as the official but the private person who is sued by Ismihan. The study of this case, in many respects confusing, reveals that the boundary between the ambassador as an official and the ambassador as a private person is very thin and can easily be overstepped.

\section{Müste'min vs. the Kadı}

All the above should not make believe that all müste'min were referring to their embassies in order to solve their court cases. In fact, it is more likely that the majority of cases were occurring out of the knowledge and the involvement of the embassies.

One of the main scenarios or at least, the most surprising is the one of the freeing of slaves (esir). According to the consulted sicill, it seems that European embassies were rarely involved in cases of slaves release brought to local justice. Indeed, several cases indicate that müste'min could refer to the kadı in order to establish legally the amount and the practical means of the collecting of the ransom for the release of a slave. However, in these specific cases, neither the ambassador nor the dragoman of the embassy are present.

The absence of the embassy is particularly surprising since one of the main roles of Western ambassadors was precisely to negotiate the release of their countrymen (sometimes also prisoners from other nationalities). The fact that there is only one unique case in which the Venetian ambassador intervenes ${ }^{36}$ indicates that prisoner slaves had other means to secure their release by paying a ransom. But we must also keep in mind that the involvement of the local court was not required for such cases and this is

35 Kuran. Mahkeme Kayıtları. $\mathrm{N}^{\circ}$ 415, p. 798-801 (Galata 27: 22b/2-1604).

36 Kuran. Mahkeme Kayıtları. $\mathrm{N}^{\circ}$ 419, p. 805-806 (Galata 27: 58a/2). 
attested by the travel accounts of released prisoners describing their adventures: the kadi's court is never mentioned. ${ }^{37}$

The majority of the cases submitted by müste'min to the local kadı without the formal involvement of the embassies is related to commercial affairs. Many of these foreign merchants were directly solving their litigation, without having recourse to their respective embassies. This phenomenon raises a question: who was asking for the support of embassies and why? The documents do not seem to suggest the answers but everything points to the likelihood that the involvement of the embassies was related to personal aspects. They were presumably responding to specific requests from individuals. Probably, the traders with no accurate knowledge of the judicial practices in force were more likely to seek help from their embassies. A connection with the ambassador or a member of the diplomatic staff could obviously help the process along. Others seem to have considered they could deal without such an intervention.

\section{Conclusion}

Within this paper, the müste'min are, in many ways, foreigners vis-à-vis the Ottoman Empire: they do not practice the dominant religion, they do not

37 On the topic of prisoners slaves in the Empire, see Vatin, Nicolas. "Une affaire interne: le sort et la libération des personnes de condition libre illégalement retenues en esclavage sur le territoire ottoman". Turcica, 33 (2001), p. 149-189; Ransom slavery along the Ottoman borders: early fifteenth-early eighteenth centuries. Pal Fodor; David Géza (eds). Leiden, Boston, Brill, 2007; Collenberg, Wipertus H. Rudt de. Esclavage et rançons des Chrétiens en Méditerranée (1570-1600): d'après les 'Litterae hortatoriae' de l'Archivio segreto Vaticano. Paris, Léopard d'or, 1987; Captifs en Méditerranée (XVI ${ }^{e}-X V I I I^{e}$ siècles). Histoires, récits et légendes. Paris, Presses de l'Université Paris-Sorbonne, 2008; Davis, Robert Charles. Esclaves chrétiens, maîtres musulmans: l'esclavage blanc en Méditerranée, 1500-180o. Paris, Chambon, 2007. See also the opposite case of Ottoman subjects that became slaves in Europe, which was the subject of few studies as Vatin, Nicolas. "Deux documents sur la libération de musulmans captifs chez les Francs (1573)". Wiener Zeitschrift für die Kunde des Morgenlandes, 83 (1993), p. 223-232; Hitzel, Frédéric. "Prisonniers des infidèles: les captifs ottomans dans l'Empire des Habsbourg (XVII ${ }^{-}$XVIII ${ }^{\mathrm{e}}$ s.)”. In: Méditerranée, Moyen-Orient, deux siècles de relations internationales. Recherches en hommage à Jacques Tobie. Walid Arbid et al. (eds). Paris, L'Harmattan, 2003, p. 185-200; Id. Prisonnier des infidèle: un soldat ottoman dans l'Empire des Habsbourg. Osmân Agha de Temechvar. Paris, Sindbad, 1998. 
belong to ethnic groups present on the territory of the Empire and last but not least, they are not subjects. However, they are required to inhabit in the Empire, for a more or less long period of time. This situation necessarily interferes with the Ottoman society.

Because of their status as/of foreigners non-subject of the Empire, müste'min are subject to a system of laws different from the other subjects of the Empire. They also benefit from advantages secured by the granting of imperial orders: the 'ahidnâme also known as the capitulations: these are prescriptions issued by the sultan, directly influenced by political and economic aspects and which may vary from one nation to another. However, it is not a code of law different from others in force in the Empire: except in specific cases prescribed by the capitulations, the müste'min are submitted as others Ottoman subjects to the Ottoman legal system.

Nevertheless, the Ottoman legal system is complex: the actors and the practices vary and depend on the individuals involved and cases. Therefore, the question that remains is who are the interlocutors of the müste'min? The documents examined here show that the type of conflicts impacted on the interlocutors that were involved. Each time the case involves, in one way or another, the privileges of the müste'min from a given nation, the imperial divan had to solve the case - then, it usually refers to the local court. But if private, the case was directly submitted to the kadı. The call for submission of cases to the Imperial divan is interesting because it shows that confidence is put in the Imperial divan rather than in the kadı. Perhaps, it also reveals the limits of the legal knowledge of the privileges and the special rights granted to müste'min. In fact, the population concerned by the Capitulations was minor and the affairs affecting them probably rare, as a result, one should not be surprised by the lack of knowledge of the local actors, of their privileges.

The role of the embassy and of the ambassador must also be emphasized here. In our documents, it appears that the embassy as a whole played a significant role in supporting its citizens through legal advice, assistance and support. The French embassy even seems to have distinguished itself on this item since the legal support offered was presented by the ambassador. In fact, it is not unusual for embassies and ambassadors to be in charge of it: they are not only the representatives of their respective sovereigns but also the protectors of their citizens. Thus, the embassy offered the help from its staff (including the dragoman) as well as its knowledge of the Ottoman legal system. This knowledge seems to have been good enough to enable them to benefit from it and to obtain some questionable advantages. 
However, some limits appear. Our documents deal with a certain number of cases. Indeed, for the XVIIth century, only the citizens from three States are concerned (Venice, France, England), which surely creates some restrictions in our analysis. What about the citizens from other states? Were there specific developments over the time? The issue of the representativeness of the cases studies is also raised: a large number of cases were treated independently from the embassy and in which the interlocutor was the kadı. Does the intervention of the embassy make these cases unique? Answering this question would require further investigation on other cities: the fact that the cases and the individuals involve inhabitants of Istanbul and of Galata could possibly impact on the way the cases are solved. The use of imperial justice was clearly facilitated by the geographical proximity and we could then wonder what about the müste'min in the provinces? 